\title{
Penyelenggara Dana Perlindungan Pemodal Bagi Investor Dalam Transaksi Saham Pada Pasar Modal
}

\author{
Mohammad Solehodin Attijani \\ solehodinaspri@yahoo.com \\ Universitas Airlangga
}

\begin{abstract}
Investors who want to invest in the capital market in Indonesia, which include securities in the form of shares, need to have a good knowledge of investment objects because basically all investments contain risk and there is no guarantee of getting profits. Investor protection fund operators have the main goal of forming investor protection funds to increase protection and trust that investors' assets are safe without being worried about the inability of securities companies to fulfill their obligations. The capital market can fail due to loss of investor distrust caused by the failure or bankruptcy of securities companies, resulting in a systemic effect that can reduce the reliability of the capital market industry. Compensation claims are given to investors who are victims of violations and / or securities crimes, not from loss of personal transactions. Investors whose assets receive investor protection funds are investors who meet the requirements set by the financial services authority.

Keywords: Organizers of Investor Protection Funds; Investor Compensation Claims.
\end{abstract}

\begin{abstract}
Abstrak
Investor yang ingin berinvestasi pada pasar modal di Indonesia, yakni antara lain surat berharga berbentuk saham, perlu memiliki pengetahuan yang baik mengenai obyek investasi karena pada dasarnya semua investasi mengandung risiko dan tidak ada jaminan pasti mendapatkan keuntungan. Penyelenggara dana perlindungan pemodal mempunyai tujuan utama membentuk dana perlindungan pemodal untuk meningkatkan perlindungan dan kepercayaan bahwa aset investor aman tanpa dihinggapi rasa khawatir atas ketidakmampuan perusahaan efek dalam memenuhi kewajibannya. Pasar modal dapat mengalami kegagalan akibat hilangnya ketidakpercayaan pemodal yang disebabkan kegagalan atau kebangkrutan perusahaan efek, sehingga menimbulkan efek sistemik yang dapat menjatuhkan kridibilitas industri pasar modal. Klaim ganti rugi diberikan kepada investor yang menjadi korban dari pelanggaran dan/atau kejahatan sekuritas, bukan dari kerugian transaksi pribadi. Investor yang asetnya mendapat dana perlindungan pemodal adalah investor yang memenuhi persyaratan yang telah ditentukan otoritas jasa keuangan.
\end{abstract}

Kata Kunci: Penyelenggara Dana Perlindungan Pemodal; Klaim Ganti Rugi Investor.

\section{Pendahuluan}

Pasar modal sebagai salah satu institusi keuangan yang berperan sebagai salah satu sarana investasi, khususnya investasi tidak langsung, harus pula berfungsi dalam menciptakan kesejahteraan rakyat. ${ }^{1}$ Bahwa dalam rangka mewujudkan kegiatan pasar modal yang teratur, wajar, dan efisien, diperlukan adanya persyaratan yang

${ }^{1}$ Lastuti Abubakar, Transaksi Derivatif di Indonesia Tinjauan Hukum Tentang Perdagangan Derivatif di Bursa Efek (Books Terrace \& Library 2009).[43]. 
wajib dipenuhi oleh pihak-pihak yang melakukan kegiatan dibidang pasar modal dan ketentuan mengenai sanksi administratif bagi pihak-pihak tertentu yang melakukan pelanggaran terhadap peraturan perundang-undangan di bidang pasar modal. ${ }^{2}$ Dengan adanya pasar modal, aktivitas perekonomian diharapkan meningkat karena pasar modal merupakan alternatif pendanaan bagi perusahaan, sehingga perusahaan dapat beroperasi dengan skala yang lebih besar dan selanjutnya akan meningkatkan pendapatan perusahaan dan kemakmuran masyarakat luas. ${ }^{3}$

Pasar modal sangat penting peranannya bagi perusahaan atau lembaga yang menginginkan modal atau dana untuk keperluan usaha, menjadi media tempat bertemunya antara penjual dan pembeli modal atau dana. ${ }^{4}$ Pasar modal merupakan wadah dan mekanisme yang mempertemukan antara pihak yangmembutuhkandanadengan pihakyangkelebihandanadalamkerangkainvestasi. ${ }^{5}$ Pasar modal memiliki peran penting bagi perekonomian suatu negara karena pasar modal menjalankan dua fungsi yaitu pertama sebagai sarana bagi pendanaan usaha atau sebagai sarana bagi perusahaan untuk mendapatkan dana dari masyarakat pemodal (investor). Dana yang diperoleh dari pasar modal dapat digunakan untuk pengembangan usaha, ekspansi, penambahan modal kerja dan lain-lain, kedua pasar modal menjadi sarana bagi masyarakat untuk berinvestasi pada instrumen keuangan seperti saham, obligasi, reksa dana, dan lain-lain. Dengan demikian, masyarakat dapat menempatkan dana yang dimilikinya sesuai karakteristik keuntungan dan resiko masing-masing instrumen. ${ }^{6}$

Pasar modal merupakan kegiatan bisnis yang sangat kompleks dan terhubung dengan persoalan-persoalan ekonomis serta yuridis. Kompleksitas persoalan yang ada dalam pasar modal disebabkan begitu banyaknya kepentingan yang saling berhadapan dan besarnya obyek transaksi yang harus menjadi perhatian dari

\footnotetext{
${ }^{2}$ Peraturan Pemerintah Nomor 45 Tahun 1995

${ }^{3}$ Tjiptono Darmadji, Hendy M. Fakhruddin, Pasar Modal di Indonesia Pendekatan Tanya Jawab (Salemba Empat 2012).[2].

${ }^{4}$ Sapto Rahardjo, Kiat Membangun Aset Kekayaan (Elex Media Komputindo 2006).[30].

${ }^{5}$ Nor Hadi, Pasar Modal Acuan Teoritis dan Praktis Investasi di Instrumen Keuangan Pasar Modal (Graha Ilmu 2013).[35].

${ }^{6}$ Didit Herlianto, Seluk Beluk Investasi di Pasar Modal Indonesia (Gosyen Publising 2010).[5].
} 
berbagai pihak. Dengan begitu banyaknya kepentingan di pasar modal, sektor yuridis menjadi suatu kebutuhan yang sangat vital dalam mengatur mekanisme pasar modal sehingga tercapai unsur ketertiban, keadilan dan kepastian hukum dalam kegiatan pasar modal. ${ }^{7}$ Pasar modal yang besar dan diperhitungkan ditentukan oleh nilai transaksi atau nilai kapitalisasi pasar dan kemampuannya untuk melindungi kepentingan para pihak terutama kepentingan investor. ${ }^{8}$ Pada dasarnya semua investasi mengandung risiko dan tidak ada jaminan pasti mendapatkan keuntungan, oleh karena itu investor agar memiliki pengetahuan yang baik mengenai obyek investasi sebelum terjun kedalamnya. ${ }^{9}$

Investor yang ingin berinvestasi perlu memahami instrumen keuangan yang dijual di pasar modal Indonesia yakni produk pasar modal antara lain surat berharga berbentuk saham. Dalam hal ini penulis memfokuskan pada penyelenggara dana perlindungan pemodal bagi investor dalam transaksi saham pada pasar modal. Penyelenggara dana perlindungan pemodal pada bursa efek Indonesia hadir dari hasil tim studi otoritas jasa keuangan (OJK).

Penyelenggara dana perlindungan pemodal (PDPP) yang dalam hal ini diwakilkan pada PT. Penyelenggara Program Perlindungan Investor Efek Indonesia (P3IEI) mempunyai tujuan utama yakni untuk meningkatkan perlindungan pemodal dan kepercayaan bahwa aset mereka aman tanpa dihinggapi rasa khawatir atas ketidakmampuan perusahaan efek dalam memenuhi kewajibannya. Pasar modal dapat mengalami kegagalan akibat hilangnya ketidakpercayaan pemodal yang disebabkan kegagalan atau kebangkrutan perusahaan efek sehingga menimbulkan efek sistemik dapat menjatuhkan kridibilitas industri pasar modal di suatu negara. ${ }^{10}$ Investor yang mendapat perlindungan ganti rugi yakni jika menjadi korban dari

\footnotetext{
${ }^{7}$ Haniefa Effendi, 'Perlindungan Bagi Pemegang Obligasi Dengan Jaminan Property (Mortgage Bond) dan Obligasi Dengan Jaminan Guarantor (Guarantor Bond)’ (2017) Tesis Fakultas Hukum Universitas Airlangga.[1].

${ }^{8}$ Rahmadiani Putri Nilasari, 'Perlindungan Hukum Terhadap Investor Dalam Transaksi Jual Beli Efek Melalui Internet’ (2011) 26 Yuridika.[275].

${ }^{9}$ Inggrid Tan, Stock Index Trading Panduan Praktis Menuai Dolar (Andi Offset 2008).[5].

${ }^{10}$ Ignatius Girendroheru, 'Pedoman Tata Kelola Perusahaan PT. Penyelenggara Program Perlindungan Investor Efek Indonesia’ (P3IEI, 2017).[3].
} 
kecurangan sekuritas, bukan dari kerugian transaksi pribadi, namun ganti rugi ini tidak secara langsung diberikan, tapi harus menunggu surat edaran dari otoritas jasa keuangan untuk memastikan klaim kerugian memang sudah selayaknya mendapatkan ganti rugi. ${ }^{11}$

Berdasarkan uraian pendahuluan diatas, dalam penelitian ini dikaji permasalahan sebagai isu hukum karakteristik dan perlindungan hukum oleh penyelenggara dana perlindungan pemodal bagi investor dalam transaksi saham pada pasar modal. Penelitian ini yang dipergunakan adalah metode penelitian normatif, dengan pendekatan perundang-undangan (statute approach) dan pendekatan konseptual (conceptual approach). Sumber bahan hukum yang digunakan dalam penelitian ini meliputi bahan hukum primer yang bersifat autoritatif artinya mempunyai otoritas, terdiri atas peraturan perundang-undangan dan bahan hukum sekunder meliputi studi kepustakaan, yang berupa buku-buku, jurnal-jurnal, majalah-majalah, artikel-artikel media, dan pelbagai sumber lain yang menunjang penulisan ini yang diperoleh melalui internet.

\section{Pengertian Penyelenggara Dana Perlindungan Pemodal Bagi Investor Dalam Transaksi Saham Pada Pasar Modal}

PDPP merupakan perseroan terbatas yang telah mendapatkan izin usaha dari OJK untuk menyelenggarakan dan mengelola DPP untuk melindungi pemodal dari hilangnya aset investor, sebagaimana diatur dalam POJK. Investor adalah pihak terpenting yang berperan di dalam kegiatan pasar modal. Bisa dikatakan salah satu indikator terpenting dalam pasar modal adalah keberadaan investor. Investor yang terlibat dalam pasar modal Indonesia adalah investor domestik dan asing, perorangan dan institusi yang mempunyai karakteristik masing-masing. Perkembangan pasar modal tidak lepas dari kebutuhan dan pengaruh investor. ${ }^{12}$ Sedangkan keberadaan

${ }^{11}$ Frisca Devi Choirina dkk, \#Yuk Belajar Saham untuk Pemula (Elex Media Komputindo 2018).[41-42].

${ }^{12}$ M. Irsan Nasarudin, Indra Surya, Ivan Yustiavandana, Arman Nefi, Adiwarman, Aspek Hukum Pasar Modal Indonesia (Kencana Prenada Media Group 2011).[165]. 
investor pada pasar modal karena adanya emiten dalam menjual efeknya. Dalam Undang-Undang Nomor 40 Tahun 2007 tentang Perseroan Terbatas (UUPT), tidak disebutkan secara khusus definisi emiten, namun dijelaskan pengertian perseroan terbatas, perseroan terbuka dan perseroan publik. Perseroan terbatas, yang selanjutnya disebut perseroan adalah badan hukum yang merupakan persekutuan modal, didirikan berdasarkan perjanjian, melakukan kegiatan usaha dengan modal dasar yang seluruhnya terbagi dalam saham dan memenuhi persyaratan yang ditetapkan dalam undang-undang ini serta peraturan pelaksanaannya. ${ }^{13}$

Perseroan terbuka adalah perseroan publik atau perseroan yang melakukan penawaran umum saham, sesuai dengan ketentuan peraturan perundangundangan di bidang pasar modal. ${ }^{14}$ Perseroan publik adalah perseroan yang memenuhi kriteria jumlah pemegang saham dan modal disetor sesuai dengan ketentuan peraturan perundang-undangan di bidang pasar modal. ${ }^{15}$ Kalau perseroan telah memenuhi kriteria sebagai perseroan publik tersebut, maka perseroan itu harus mematuhi ketentuan: ${ }^{16}$

“(1) Perseroan yang modal dan jumlah pemegang sahamnya telah memenuhi kriteria sebagai perseroan publik sesuai dengan ketentuan peraturan perundang-undangan di bidang pasar modal, wajib mengubah anggaran dasarnya sebagaimana dimaksud dalam pasal 21 ayat (2) huruf $f$ dalam jangka waktu 30 (tiga puluh) hari terhitung sejak terpenuhi kriteria tersebut; (2) Direksi perseroan sebagaimana dimaksud pada ayat (1) wajib mengajukan pernyataan pendaftaran sesuai dengan ketentuan peraturan perundangundangan di bidang pasar modal".

Perseroan publik merupakan perseroan terbuka, yang mana untuk menjadi perseroan publik, perseroan harus memenuhi kriteria yaitu bila sahamnya dimiliki sekurang-kurangnya 300 pemegang saham, modal disetornya berjumlah Rp. 3 miliar, dan/atau ditetapkan lain dengan Peraturan Pemerintah. ${ }^{17}$ Jadi untuk dapat disebut sebagai perseroan publik, tidak harus saham-sahamnya ditawarkan di pasar

\footnotetext{
${ }^{13}$ Pasal 1 angka (1) UUPT.

${ }^{14}$ Pasal 1 angka (7) UUPT.

${ }^{15}$ Pasal 1 angka (8) UUPT.

${ }^{16}$ Pasal 24 UUPT.

${ }^{17}$ Pasal 1 angka (22) UUPM.
} 
modal. Jika ada suatu perseroan terbatas yang sekalipun saham-sahamnya tidak ditawarkan dalam pasar modal, tetapi jika jumlah sahamnya dan modal disetornya memenuhi peraturan perundang-undangan di pasar modal, maka perseroan terbatas ini dinamakan perseroan terbatas publik dan terhadap perseroan terbatas publik ini selain berlaku ketentuan-ketentuan tentang perseroan terbatas, berlaku pula ketentuan-ketentuan di pasar modal. ${ }^{18}$ Sedangkan perseroan terbuka lebih luas, perseroan terbuka (Tbk) bisa: ${ }^{19}$

a. Perseroan publik yang telah memenuhi kriteria sebagai perseroan publik yaitu memiliki pemegang saham sekurangnya 300 orang dan modal disetor sekurangkurangnya Rp. 3 miliar; atau

b. Perseroan yang melakukan penawaran umum (public offering) saham di bursa efek (emiten). Maksudnya perseroan tersebut menawarkan atau menjual saham atau efeknya kepada masyarakat luas.

Berdasarkan Undang-Undang Nomor 8 Tahun 1995 tentang Pasar Modal (UUPM), secara singkat disebutkan emiten: ${ }^{20}$

a. Pihak yang melakukan kegiatan penawaran efek kepada masyarakat untuk menjual efek berdasarkan tata cara yang diatur dalam Undang-Undang Pasar Modal dan peraturan pelaksanaannya;

b. Dapat berupa orang perseorangan, perusahaan, usaha bersama, asosiasi, atau kelompok yang terorganisasi.

Setiap emiten memiliki kode perdagangan tersendiri seperti PT. Astra Internasional Tbk kodenya yaitu ASII, PT. Semen Indonesia Tbk (SMGR), PT. Wijaya Karya Tbk (WIKA) dan PT. Bank Rakyat Indonesia (BBRI). ${ }^{21}$ Proses aliran dana dari masyarakat pemodal pada perusahaan harus jelas dan pasti. Kepastian

\footnotetext{
${ }^{18}$ Rudhi Prasetya, Teori \& Praktek Perseroan Terbatas (Sinar Grafika 2016).[93].

${ }^{19}$ No name, 'Perbedaan Emiten dan Perusahaan Publik', <https://www.sahamok.com/perbedaan-emiten-dan-perusahaan-publik/> diakses pada tanggal 3 Desember 2018.

${ }^{20}$ Sovia Hasanah, 'Perbedaan Perseroan Terbuka dengan Perseroan Publik', $<$ https://www. hukumonline.com/index.php/klinik/detail/lt59d19e8d6de3d/perbedaan-perseroan-terbuka-dengan-perseroan-publik $>$ diakses pada tanggal 3 Desember 2018.

${ }^{21}$ No name, 'Pengertian dan Contoh Emiten', <http://istilah-istilahsaham.blogspot. com/2017/09/sumber-sahamok.html> diakses pada tanggal 3 Desember 2018.
} 
ini dapat terlaksana dengan kehadiran penjamin emisi efek. Masyarakat pemodal yang menanamkan modalnya pada perusahaan harus ada suatu jaminan, bahwa perusahaan tersebut sehat, untuk itu setiap perusahaan yang go public, laporan keuangannya harus diaudit oleh akuntan publik minimal 2 (dua) tahun terakhir dan harus disertai pendapat setuju tidak bersyarat, yang berarti perusahaan benarbenar dalam keadaan sehat. ${ }^{22}$ Menerbitkan saham merupakan salah satu pilihan perusahaan ketika memutuskan untuk pendanaan perusahaan. Pada sisi lain, saham merupakan instrument investasi yang banyak dipilih para investor karena saham mampu memberikan tingkat keuntungan yang menarik. Saham dapat didefinisikan sebagai tanda penyertaan modal seseorang atau pihak (badan usaha) dalam suatu perusahaan atau perseroan terbatas. Dengan menyertakan modal tersebut, maka pihak tersebut memiliki klaim atas pendapatan perusahaan, klaim atas asset perusahaan, dan berhak hadir dalam rapat umum pemegang saham (RUPS). ${ }^{23}$ Setiap saham harus mempunyai nilai nominal, karena UUPT melarang suatu perusahaan menerbitkan saham tanpa nilai nominal, namun memberikan kemungkinan untuk saham yang dikeluarkan tanpa nilai nominal asal UUPM mengaturnya. ${ }^{24}$

\section{Karakteristik Penyelenggara Dana Perlindungan Pemodal Bagi Investor Dalam Transaksi Saham Pada Pasar Modal}

Bekerjanya hukum tidak dapat dilepaskan dari kemampuan profesional hukum dalam pelayanan yang diberikan kepada masyarakat di sekelilingnya. Hukum tidak bekerja menurutukuran dan pertimbangannya sendiri, melainkan dengan memikirkan dan mempertimbangkan apa yang baik untuk dilakukannya bagi masyarakat. ${ }^{25}$ Jika profesionalisme dikaitkan dengan penyelenggara dana perlindungan pemodal

\footnotetext{
${ }^{22}$ Christma Dasse Ardhani, 'Perlindungan Hukum Terhadap Pemegang Saham Minoritas Perusahaan Publik’ (2016) Tesis Fakultas Hukum Universitas Airlangga.[8].

${ }^{23}$ Didit Herlianto, Op.Cit.[11].

${ }^{24}$ James Julianto Irawan, Surat Berharga Suatu Tinjauan Yuridis dan Praktis (Kencana Prenadamedia Group 2014).[167].

${ }^{25}$ Flora Pricilla Kalalo, Praktek Hukum dalam Bingkai Moral dalam buku Hukum Sebagai Pancaran Moral Dalam Rangka Memperingati 70 Tahun Guru, Sahabat, dan Bapak Kami Prof. Dr. Peter Mahmud Marzuki, S.H., M.S., LL.M (Prenadamedia Group 2019).[246].
} 
bagi investor dalam transaksi saham pada pasar modal, maka mengharuskan adanya kewenangan yang memadai dalam mempraktikan hukum, yang dalam hal ini sebagai penyelenggara yang telah memperoleh izin dari otoritas dalam melakukan perlindungan dana pemodal. OJK mempunyai kewenangan untuk menyelenggarakan sistem pengaturan dan pengawasan yang terintegrasi terhadap keseluruhan kegiatan di dalam sektor jasa keuangan di bidang pasar modal. ${ }^{26}$ Tugas pengaturan pasar modal: ${ }^{27}$

a. Menetapkan peraturan pelaksanaan dari Undang-Undang Nomor 21 Tahun 2011 tentang Otoritas Jasa Keuangan (UUOJK);

b. Menetapkan peraturan perundang-undangan di sektor jasa keuangan;

c. Menetapkan peraturan dan keputusan OJK;

d. Menetapkan peraturan mengenai pengawasan di sektor jasa keuangan;

e. Menetapkan kebijakan mengenai pelaksanaan tugas OJK;

f. Menetapkan peraturan mengenai tata cara penetapan perintah tertulis terhadap lembaga jasa keuangan dan pihak tertentu;

g. Menetapkan peraturan mengenai tata cara penetapan pengelola statuter pada lembaga jasa keuangan;

h. Menetapkan struktur organisasi dan infrastruktur, serta mengelola, memelihara, dan menatausahakan kekayaan dan kewajiban; dan

i. Menetapkan peraturan mengenai tata cara pengenaan sanksi sesuai dengan ketentuan peraturan perundang-undangan di sektor jasa keuangan.

Untuk melaksanakan tugas pengawasan pasar modal: ${ }^{28}$

a. Menetapkan kebijakan operasional pengawasan terhadap kegiatan jasa keuangan;

b. Mengawasi pelaksanaan tugas pengawasan yang dilaksanakan oleh kepala eksekutif;

c. Melakukan pengawasan, pemeriksaan, penyidikan, perlindungan konsumen, dan tindakan lain terhadap lembaga jasa keuangan, pelaku, dan/ atau penunjang kegiatan jasa keuangan sebagaimana dimaksud dalam peraturan perundangundangan di sektor jasa keuangan;

d. Memberikan perintah tertulis kepada lembaga jasa keuangan dan/atau pihak tertentu;

e. Melakukan penunjukan pengelola statuter;

f. Menetapkan penggunaan pengelola statuter;

g. Menetapkan sanksi administratif terhadap pihak yang melakukan pelanggaran

${ }^{26}$ Andika Wijaya, Wida Peace Ananta, IPO Right Issue \& Penawaran Umum Obligasi (Sinar Grafika 2018).[17].

${ }^{27}$ Pasal 8 UUOJK.

${ }^{28}$ Pasal 9 UUOJK. 
terhadap peraturan perundang-undangan di sektor jasa keuangan; dan

h. Memberikan dan/ atau mencabut :

1) Izin usaha;

2) Izin orang perseorangan;

3) Efektifnya pernyataan pendaftaran;

4) Surat tanda terdaftar;

5) Persetujuan melakukan kegiatan usaha;

6) Pengesahan;

7) Persetujuan atau penetapan pembubaran; dan

8) Penetapan lain, sebagai dimaksud dalam peraturan perundang-undangan di sektor jasa keuangan.

Pemegang saham PDPP adalah self regulatory organization (SRO) terdiri dari

BEI, KPEI, dan KSEI. ${ }^{29}$ OJK dan SRO memberikan tugas kepada penyelenggara dana perlindungan pemodal (Investor protection fund) dengan karakteristik untuk melindungi kepentingan pemodal (investor) terhadap bahaya kehilangan aset, yaitu: ${ }^{30}$

a. DPP merupakan kumpulan dana yang dibentuk untuk melindungi pemodal dari hilangnya aset pemodal;

b. Pemodal adalah nasabah dari perantara pedagang efek yang mengadministrasikan rekening efek nasabah dan bank kustodian;

c. Aset pemodal adalah efek dan harta lain yang berkaitan dengan efek, dan/atau dana milik pemodal yang dititipkan pada kustodian :

1) Efek dalam penitipan kolektif pada kustodian yang dicatat dalam rekening efek pada lembaga penyimpanan dan penyelesaian.

2) Dana yang dititipkan pada kustodian yang dibukakan rekening dana nasabah pada bank atas nama masing-masing pemodal.

d. PDPP adalah perseroan yang telah mendapatkan izin usaha dari OJK untuk menyelenggarakan dan mengelola DPP. Dalam hal ini diamanatkan kepada Indonesia SIPF.

DPP dihimpun dari lima sumber utama yakni: ${ }^{31}$

a. Pertama dari self regulatory organizations;

b. Kedua dari iuran keanggotaan dari perantara pedagang efek dan bank kustodian;

c. Ketiga berasal dari perantara pedagang efek dan bank kustodian yang terbukti

\footnotetext{
${ }^{29}$ Pasal 7 ayat (4) Peraturan Otoritas Jasa Keuangan Nomor 50/POJK.04/2016 tentang Penyelenggara Dana Perlindungan Pemodal.

${ }^{30}$ Indonesia SIPF Securities Investor Protection Fund, 'Definisi', $<$ http://indonesiasipf.co.id/ dana-perlindungan-pemodal > diakses pada tanggal 1 Mei 2019.

${ }^{31}$ Indonesia SIPF Securities Investor Protection Fund, 'Bulletin April 2018, Wajah Baru Indonesia SIPF', <http://www.indonesiasipf.co.id/uploads/media/isipfbulletin2018q1.pdf> diakses pada tanggal 1 Mei 2019.
} 
melakukan pelanggaran dan/atau kejahatan terhadap pemodal.

d. Keempat berasal dari hasil investasi DPP pada surat berharga negara dan/atau deposito pada bank dari bumn.

Beberapa ketentuan DPP: $:^{2}$

a. Bukan merupakan milik pihak tertentu dan tidak digunakan untuk keperluan apapun, kecuali untuk tujuan sebagaimana ditentukan dalam POJK Nomor 49/ POJK.04/2016 tentang DPP;

b. Digunakan untuk memberikan ganti rugi kepada pemodal atas hilangnya aset pemodal;

c. Hanya dapat diinvestasikan pada surat berharga negara dan/atau deposito pada bank dari bumn;

d. Tidak dapat dipinjamkan atau dijaminkan;

e. PDPP berhak mendapatkan imbalan atas jasa pengelolaan atas investasi DPP sebesar 10\% (sepuluh perseratus) dari pendapatan bersih hasil investasi.

Dalam keadaan tertentu, OJK dapat mengambil alih dan menetapkan penggunaan DPP. ${ }^{33}$

\section{Bentuk Perlindungan Hukum Penyelenggara Dana Perlindungan Pemodal Bagi Investor Dalam Transaksi Saham Pada Pasar Modal}

Perlindungan hukum bagi pemodal (investor) bahkan telah menjadi tema krusial dalam pembicaraan mengenai bisnis pasar modal. Pengawasan pasar modal terutama ditujukan demi terwujudnya perlindungan hukum bagi pemodal (investor). Terwujudnya perlindungan hukum yang baik, menjadi salah satu prasyarat bagi pengembangan pasar modal mengingat kegiatan bisnis di dalam pasar modal juga merupakan bisnis kepercayaan, pemeliharaan pemodal menjadi faktor penentu bagi kelangsungan dan perkembangan pasar modal itu sendiri, serta memberikan rasa aman dan nyaman bagi para investor.

Pelanggaran dan/atau kejahatan pada pasar modal terkait dengan perdagangan efek (saham) di bursa yang dilakukan antar perusahaan sekuritas yang bertindak sebagai perantara pedagang efek/broker efek. Sedangkan pembentukan harga efek

\footnotetext{
${ }^{32}$ Indonesia SIPF Securities Investor Protection Fund, 'Dana Perlindungan Pemodal', $<$ http:// www.indonesiasipf.co.id/dana-perlindungan-pemodal> diakses pada tanggal 2 Mei 2019.

${ }^{33}$ Pasal 14 Peraturan Otoritas Jasa Keuangan Nomor 49/POJK.04/2016 tentang Dana Perlindungan Pemodal.
} 
(saham) terjadi karena adanya faktor supply (penawaran) dan demand (permintaan): ${ }^{34}$ a. Mikro-ekonomi (kinerja perusahaan, kinerja industri dimana perusahaan tersebut bergerak, perubahan manajemen perusahaan, produktivitas karyawan, harga bahan baku, ketersediaan bahan baku, prospek penjualan, dan lain-lain);

b. Makro-ekonomi (tingkat suku bunga, inflasi, nilai tukar, tingkat pengangguran, tingkat konsumsi publik, dan kondisi ekonomi dunia); dan

c. Non-ekonomi (kondisi sosial politik, bencana, dan faktor lain).

Perubahan volume perdagangan kearah yang lebih baik berarti menunjukkan tanda optimism pasar, sebaliknya penurunan volume perdagangan menunjukkan tanda pesimisme pasar. ${ }^{35}$ Sehingga investor yang menanamkan modalnya, hukum wajib mengatur dan melindunginya, karena tingkat risiko tinggi akan adanya pelanggaran dan/atau kejahatan investasi dalam perdagangan saham pada pasar modal, dimana investor beli dan investor jual tidak pernah bertemu langsung sebab investor melakukan pesanan beli atau pesanan jual dilakukan melalui broker efek. ${ }^{36}$ Selanjutnya broker efek yang melaksanakan order jual beli di antara mereka, broker efek menyampaikan informasi kepada investor bahwa order investor sudah dilaksanakan atau gagal dilaksanakan. Dalam melakukan transaksi atau perdagangan efek, setiap investor diwakili oleh perantara pedagang efek. ${ }^{37}$ Hubungan kepercayaan perusahaan sekuritas sebagai perantara pedagang efek dengan investor inilah yang dapat menjadi awal adanya pelanggaran dan kejahatan pada pasar modal, jika tidak dijaga dengan baik. Pelanggaran dan kejahatan pasar modal, berdasarkan Bab XI Pasal 90-99 UUPM, mengategorikan dalam tiga hal:

a. Penipuan (Fraud)

Mengenai tindak pidana penipuan di pasar modal diatur didalam UUPM yang mengatur bahwa dalam kegiatan perdagangan efek, setiap pihak dilarang

\footnotetext{
${ }^{34}$ Cita Yustisia Serfiyani, R. Serfianto D. Purnomo, Iswi Hariyani, Capital Market Top Secret Ramuan Sukses Bisnis Pasar Modal Indonesia (Andi 2017).[315].

${ }^{35}$ Aski Catranti, 'Pengaruh Right Issue terhadap Imbal Balik Saham dan Volume Perdagangan' (2009) 16 Jurnal Ilmu Administrasi dan Organisasi.[191].

${ }^{36}$ Mohamad Samsul, Pasar Modal \& Manajemen Porto folio (Erlangga 2015).[106].

${ }^{37}$ Gunawan Widjaja, Seri Aspek Hukum Dalam Pasar Modal Penitipan Kolektif(RajaGrafindo Persada 2006).[173].
} 
baik secara langsung maupun tidak langsung: ${ }^{38}$

1) Menipu atau mengelabui pihak lain dengan menggunakan sarana dan cara apa pun;

2) Turut serta menipu;

3) Membuat pernyataan tidak benar mengenai fakta materiil atau tidak mengungkapkan mengenai keadaan yang terjadi pada saat pernyataan dibuat dengan maksud menguntungkan atau menghindarkan kerugian untuk diri sendiri atau pihak lain atau dengan tujuan memengaruhi pihak lain untuk membeli atau menjual efek.

Lingkup penipuan di pasar modal dibatasi pada penipuan dalam kaitannya dengan perdagangan efek yang meliputi kegiatan penawaran, pembelian dan/atau penjualan efek yang terjadi dalam rangka penawaran umum atau terjadi di bursa efek, maupun kegiatan penawaran, pembelian dan/atau penjualan efek di luar bursa efek atau efek perusahaan publik atau emiten. ${ }^{39}$

Ketentuan tentang penipuan dalam perdagangan pada pasar modal memiliki hubungan potensial terjadi antara perusahaan efek dengan investornya, sehingga pedoman perilaku yang mengatur tentang larangan dan kewajiban perusahaan efek dalam hubungan dan menjaga kepentingan rekening dan harta kekayaan investor yaitu saham menjadi objek utama pengaturan-pengaturan untuk mencegah terjadinya tindak pidana penipuan..$^{40}$

b. Manipulasi Pasar (Market Manipulation)

Manipulasi pasar merupakan kegiatan yang dilarang karena merupakan kegiatan yang dapat merusak integritas pasar modal dan kepercayaan masyarakat pada aktivitas di pasar modal, kepercayaan masyarakat sangat penting karena kepercayaan publik dapat meningkatkan likuiditas dan efisiensi pasar. ${ }^{41}$ Larangan manipulasi pasar sebagaimana diatur didalam UUPM, yaitu: ${ }^{42}$

1) Setiap pihak dilarang melakukan tindakan baik langsung maupun tidak langsung dengan tujuan untuk menciptakan gambaran semu atau menyesatkan

\footnotetext{
${ }^{38}$ Pasal 90 UUPM.

${ }^{39}$ Mas Rahmah, Hukum Pasar Modal (Kencana 2019).[377-378].

${ }^{40}$ Nindyo Pramono, Hukum PT Go Public \& Pasar Modal (Andi 2013).[327].

${ }^{41}$ ibid. [379-380].

${ }^{42}$ Pasal 91-93 UUPM.
} 
mengenai kegiatan perdagangan, keadaan pasar atau harga efek;

2) Setiap pihak baik sendiri-sendiri maupun bersama-sama dilarang melakukan dua transaksi efek atau lebih, baik langsung maupun tidak langsung menyebabkan harga efek di bursa efek tetap naik atau tetap turun dengan tujuan memengaruhi pihak lain untuk membeli, menjual atau menahan efek;

3) Setiap pihak dilarang dengan cara apapun, membuat pernyataan atau memberikan keterangan yang secara materiil tidak benar atau menyesatkan sehingga memengaruhi harga efek di bursa efek apabila pada saat pernyataan dibuat atau keterangan diberikan :

a) Pihak yang bersangkutan mengetahui atau sepatutnya mengetahui bahwa pernyataan atau keterangan tersebut secara materiil tidak benar atau menyesatkan; atau

b) Pihak yang bersangkutan tidak cukup berhati-hati dalam menentukan kebenaran informasi dari pernyataan atau keterangan tersebut.

Manipulasi pasar adalah segala jenis tindakan hukum yang berupa berbagai jenis pernyataan tertentu yang dapat mengakibatkan terjadinya kondisi yang tidak fair, tidak transparan dan merugikan orang lain di bursa efek, yang dapat dilakukan oleh siapapun yang terkait erat dengan bursa efek, seperti misalnya emiten, perusahaan efek, lembaga penunjang, profesi penunjang pasar modal, pialang, bahkan investor atau wartawan. ${ }^{43}$

c. Perdagangan Orang Dalam (Insider Trading)

Pada dasarnya insider trading merupakan transaksi efek yang dilakukan orang dalam (insider) berdasarkan informasi orang dalam yang belum dibuka kepada publik (non public information/inside information). ${ }^{44}$ Menurut Utpal Bhattacharya dan Hazem Daouk: $:^{45}$

Insider trading is the trading of a public company's stock or other securities (such as bonds or stock options) by individuals with access to non-public

\footnotetext{
${ }^{43}$ Nindyo Pramono, Op.Cit.[328].

${ }^{44}$ Mas Rahmah, Op.Cit.[386].

${ }^{45}$ Utpal Bhattacharya, Hazem Daouk, 'The World Price of Insider Trading' (2002) LVII Journal of Finance.[75].
} 
information about the company. In various countries, trading based on insider information is illegal.

Perdagangan orang dalam adalah perdagangan efek illegal yang merupakan kategori pelanggaran dan/atau kejahatan pasar modal. Mendasarkan UUPM, larangan orang dalam meliputi: ${ }^{46}$

1) Komisaris, direktur, atau pegawai emiten atau perusahaan publik;

2) Pemegang saham utama emiten atau perusahaan publik;

3) Orang perorangan yang karena kedudukannya atau profesinya atau karena hubungan usahanya dengan emiten atau perusahaan publik memungkinkan orang tersebut memperoleh informasi orang dalam;

4) Pihak yang dalam waktu enam bulan terakhir tidak lagi menjadi pihak sebagaimana disebut dalam angka 1, 2, dan 3.

Sedangkan informasi atau fakta materiil yang diperkirakan dapat mempengaruhi harga efek dan keputusan investasi investor, meliputi: ${ }^{47}$

1) Penggabungan usaha, pembelian saham, peleburan usaha, atau pembentukan usaha patungan;

2) Pemecahan saham atau pembagian dividen saham;

3) Pendapatan dari dividen yang luar biasa sifatnya;

4) Perolehan atau kehilangan kontrak penting;

5) Produk atau penemuan baru yang berarti;

6) Perubahan dalam pengendalian atau perubahan penting dalam manajemen;

7) Pengumuman pengembalian kembali atau pembayaran efek yang bersifat utang;

8) Penjualan tambahan efek kepada masyarakat atau secara terbatas yang material jumlahnya;

9) Pembelian, atau kerugian penjualan aktiva yang materiil;

10)Perselisihan tenaga kerja yang relative penting

11) Tuntutan hukum yang penting terhadap perusahaan dan/atau direktur dan komisaris perusahaan;

12)Pengajuan tawaran untuk pembelian efek perusahaan lain;

13)Penggantian wali amanat;

14)Perubahan tahun fiskal perusahaan.

Larangan insider trading berlaku untuk tiga pihak, yaitu: ${ }^{48}$

1) Orang dalam;

\footnotetext{
${ }^{46}$ Pasal 95 UUPM.

${ }^{47}$ Keputusan Ketua Bapepam Nomor Kep-86/PM/1996 perihal Peraturan Nomor X.K.1 tentang Keterbukaan Informasi Yang Harus Segera Diumumkan Kepada Publik.

${ }^{48}$ Mas Rahmah, Op.Cit.[397].
} 
2) Pihak yang memperoleh informasi secara melawan hukum atau tanpa melawan hukum tetapi dengan pembatasan;

3) Perusahaan efek.

Jika orang dalam yang jelas-jelas berpotensi memiliki akses informasi lebih dahulu dari pada publik dibiarkan boleh melakukan transaksi atau memberikan informasi tersebut kepada kroni atau orang lain yang berpotensi mendatangkan keuntungan, maka citra bursa pasar modal yang harus transparan, wajar, tertib, teratur dan likuid serta efisien pasti akan ternodai dan terganggu. ${ }^{49}$ Tujuan larangan perdagangan oleh orang dalam, agar informasi yang keluar dari perusahaan dapat sampai kepada semua orang (pemodal) secara merata terlebih dahulu sehingga tidak ada satu pihak pun yang diuntungkan, baik karena hubungan yang bersangkutan dengan perusahaan maupun karena yang bersangkutan memperolehnya secara melawan hukum. ${ }^{50}$ Pada pelaksanaan praktik insider trading di bursa saham motif utama para pelaku adalah mendapatkan keuntungan, namun keuntungan ini tidak dibenarkan sebab diusahakan dengan cara yang tidak legal secara hukum maupun tidak etis secara etika perdagangan bursa. ${ }^{51}$

Syarat pemodal (investor) yang asetnya mendapat perlindungan: ${ }^{52}$

a. Memiliki rekening efek pada kustodian;

b. Memiliki single investor identification.

Sedangkan pemodal (investor) yang asetnya tidak mendapatkan DPP. ${ }^{53}$

a. Pemodal yang terlibat atau menjadi penyebab aset pemodal hilang;

b. Pemodal merupakan pemegang saham pengendali, direktur, komisaris, atau pejabat satu tingkat di bawah direktur kustodian; dan/atau

c. Pemodal merupakan afiliasi dari pihak-pihak tersebut pada angka 1 dan 2 . Aset pemodal yang tidak menjadi bagian dari DPP sebagaimana disebut diatas, juga mencakup yakni nilai kerugian atas perkiraan nilai investasi masa datang

\footnotetext{
${ }^{49}$ Nindyo Pramono, Op.Cit.[330].

${ }^{50}$ Hamud M. Balfas, 'Tindak Pidana Pasar Modal dan Pengawasan Perdagangan di Bursa Efek’ (1999) 6 Jurnal Hukum Ius Quia Iustum.[90].

${ }^{51}$ Fadilah Haidar, 'Perlindungan Hukum Bagi Investor Terhadap Praktik Kejahatan Insider Trading Pada Pasar Modal Di Indonesia’ (2015) 3 Jurnal Cita Hukum.[147].

${ }^{52}$ Indonesia SIPF Securities Investor Protection Fund, 'Perlindungan Pemodal', <http:// indonesiasipf.co.id/perlindungan-pemodal> diakses pada tanggal 2 Mei 2019.

53 ibid.
} 
dan transaksi yang dilakukan secara over the counter (OTC) atau transaksi diluar bursa.

PDPP melakukan penanganan klaim pemodal setelah OJK menetapkan: ${ }^{54}$

a. Terdapat kehilangan aset pemodal;

b. Kustodian tidak memiliki kemampuan untuk mengembalikan aset pemodal yang hilang;

c. Bagi kustodian berupa perantara pedagang efek yang mengadmini-strasikan efek dinyatakan tidak dapat melanjutkan kegiatan usahanya dan dipertimbangkan izin usahanya dicabut oleh otoritas jasa keuangan; atau

d. Bagi bank kustodian dinyatakan tidak dapat melanjutkan kegiatan usahanya sebagai bank kustodian dan dipertimbangkan persetujuan bank umum sebagai kustodian dicabut oleh otoritas jasa keuangan.

Dalam waktu paling lambat 3 (tiga) hari kerja setelah menerima penetapan dari OJK, PDPP wajib: ${ }^{55}$

a. Mengumumkan ke masyarakat melalui surat kabar / media lainnya jika terjadi peristiwa dimaksud di atas dan mengundang pemodal terkait agar menyampaikan klaim kepada penyelenggara dana perlindungan pemodal dalam waktu tidak lebih dari 30 (tiga puluh) hari kerja sejak pengumuman dilakukan;

b. Mengusulkan pembentukan komite klaim kepada OJK; dan

c. Membentuk tim verifikasi klaim.

Kriteria pembayaran ganti rugi kepada pemodal (investor) dengan menggunakan DPP. 56

a. Efek pemodal yang ada di sub rekening efek di lembaga penyimpanan dan penyelesaian tidak menunjukkan jenis yang sama dan/atau menunjukkan jumlah yang lebih sedikit dari yang seharusnya dimiliki oleh pemodal; dan/atau

b. Dana yang tercatat di rekening dana nasabah pada bank atas nama pemodal lebih sedikit dari yang seharusnya dimiliki oleh pemodal.

\footnotetext{
${ }^{54}$ Indonesia SIPF Securities Investor Protection Fund, 'Tahapan Penanganan Klaim', <http:// indonesiasipf.co.id/perlindungan-pemodal $>$ diakses pada tanggal 2 Mei 2019.

${ }^{55}$ ibid.

${ }^{56}$ Surat Edaran Otoritas Jasa Keuangan Nomor 18/SEOJK.04/2013 tentang Kriteria Pernyataan Tertulis Oleh Otoritas Jasa Keuangan Dan Tata Cara Penentuan Nilai Aset Pemodal Yang Hilang, Dalam Rangka Penggunaan Dana Perlindungan Pemodal.
} 
Besaran batasan ganti rugi aset pemodal sesuai ketentuan yang tertuang pada Keputusan Anggota Dewan Komisioner OJK Nomor 46/D.04/2015 ditetapkan batasan paling tinggi Rp 100 juta per investor dan Rp. 50 miliar per bank kustodian. Penggantian aset pemodal di pasar saham hanya diganti oleh Indonesia Securities Investor Protection Fund (Indonesia SIPF) jika ada fraud atau penipuan atau penyalahgunaan dana oleh perusahaan efek (broker) dan/atau kustodian yang menjadi anggota Indonesia Securities Investor Protection Fund (Indonesia SIPF). ${ }^{57}$ Adapun proses klaim aset pemodal: ${ }^{58}$

a. OJK mengeluarkan pernyataan telah terpenuhi kondisi hilangnya aset investor;

b. PDPP mempublikasi dan mengundang investor yang bersangkutan;

c. Pemodal menyampaikan permohonan klaim secara tertulis;

d. Tim verifikasi melakukan pemeriksaan;

e. Komite klaim melakukan penelaahan atas hasil verikasi yang dilakukan oleh tim verikasi klaim dan kemudian menyusun rekomendasi kepada PDPP;

f. Berdasarkan rekomendasi dari komite klaim, PDPP membayar kerugian yang diderita investor.

Berdasarkan Pasal 44 ayat (1-3) POJK Nomor 50/POJK.04/2016 mengatur anggota direksi penyelenggara dana perlindungan pemodal membentuk komite klaim dengan susunan anggota paling sedikit 7 orang, yang terdiri dari 2 orang pejabat otoritas jasa keuangan, 3 orang perwakilan dari self regulatory organizations, 1 orang anggota direksi PDPP, dan 1 orang profesional di bidang pasar modal atau lembaga perlindungan konsumen.

\section{Kesimpulan}

Klaim ganti rugi investor kepada PDPP yang sangat krusial, terdapat pada penetapan OJK yang menyatakan terdapat kondisi kehilangan aset pemodal atas penyalahgunaan kepercayaan atau kebangkrutan anggota (perusahaan efek dan/ atau kustodian) dan besaran batasan ganti rugi aset pemodal. Adapun persyaratan

\footnotetext{
${ }^{57}$ Tahir Saleh, 'Perhatian! Emiten Pailit, SIPF Tak Ganti Dana Investor', <https://www. cnbcindonesia.com/market/20190508105900-17-71193/perhatian-emiten-pailit-sipf-tak-gantidana-investor $>$ diakses pada tanggal 2 Mei 2019.

58 'Peningkatan Dana Ganti Rugi Investor Untuk Kenyamanan Berinvestasi”, Forum Kustodian Efek Indonesia (Fokuss 2015).[4].
} 
penanganan klaim mendasarkan pada POJK Nomor 49/POJK.04/2016 tentang DPP dan POJK Nomor 50/POJK.04/2016 tentang PDPP.

\section{Daftar Bacaan}

\section{Buku}

Andika Wijaya, Wida Peace Ananta, IPO Right Issue \& Penawaran Umum Obligasi (Sinar Grafika 2018).

Cita Yustisia Serfiyani, R. Serfianto D. Purnomo, Iswi Hariyani, Capital Market Top Secret Ramuan Sukses Bisnis Pasar Modal Indonesia (Andi 2017).

Didit Herlianto, Seluk Beluk Investasi di Pasar Modal Indonesia (Gosyen Publising 2010).

Flora Pricilla Kalalo, Praktek Hukum dalam Bingkai Moral dalam buku Hukum Sebagai Pancaran Moral Dalam Rangka Memperingati 70 Tahun Guru, Sahabat, dan Bapak Kami Prof. Dr. Peter Mahmud Marzuki, S.H., M.S., LL.M (Prenadamedia Group 2019).

Frisca Devi Choirina dkk, \#Yuk Belajar Saham untuk Pemula (Elex Media Komputindo 2018).

Gunawan Widjaja, Seri Aspek Hukum Dalam Pasar Modal Penitipan Kolektif (RajaGrafindo Persada 2006).

Inggrid Tan, Stock Index Trading Panduan Praktis Menuai Dolar (Andi Offset 2008).

James Julianto Irawan, Surat Berharga Suatu Tinjauan Yuridis dan Praktis (Kencana Prenadamedia Group 2014).

Lastuti Abubakar, Transaksi Derivatif di Indonesia Tinjauan Hukum Tentang Perdagangan Derivatif di Bursa Efek (Books Terrace \& Library, Bandung 2009).

M. Irsan Nasarudin, Indra Surya, Ivan Yustiavandana, Arman Nefi, Adiwarman, Aspek Hukum Pasar Modal Indonesia (Kencana Prenada Media Group 2011).

Mas Rahmah, Hukum Pasar Modal (Kencana 2019).

Mohamad Samsul, Pasar Modal \& Manajemen Porto folio (Erlangga 2015).

Nindyo Pramono, Hukum PT Go Public \& Pasar Modal (Andi 2013). 
Nor Hadi, Pasar Modal Acuan Teoritis dan Praktis Investasi di Instrumen Keuangan Pasar Modal (Graha Ilmu 2013).

Rudhi Prasetya, Teori \& Praktek Perseroan Terbatas (Sinar Grafika 2016).

Sapto Rahardjo, Kiat Membangun Aset Kekayaan (Elex Media Komputindo 2006).

Tjiptono Darmadji, Hendy M. Fakhruddin, Pasar Modal di Indonesia Pendekatan Tanya Jawab (Salemba Empat 2012).

\section{Jurnal}

Aski Catranti, 'Pengaruh Right Issue terhadap Imbal Balik Saham dan Volume Perdagangan’ (2009) 16 Jurnal Ilmu Administrasi dan Organisasi.

Fadilah Haidar, 'Perlindungan Hukum Bagi Investor Terhadap Praktik Kejahatan Insider Trading Pada Pasar Modal Di Indonesia’ (2015) 3 Jurnal Cita Hukum.

Hamud M. Balfas, 'Tindak Pidana Pasar Modal dan Pengawasan Perdagangan di Bursa Efek' (1999) 6 Jurnal Hukum Ius Quia Iustum.

Ignatius Girendroheru, 'Pedoman Tata Kelola Perusahaan PT. Penyelenggara Program Perlindungan Investor Efek Indonesia' (P3IEI 2017).

No name, 'Peningkatan Dana Ganti Rugi Investor Untuk Kenyamanan Berinvestasi', Forum Kustodian Efek Indonesia (Fokuss 2015).

Rahmadiani Putri Nilasari, 'Perlindungan Hukum Terhadap Investor Dalam Transaksi Jual Beli Efek Melalui Internet' (2011) 26 Yuridika.

Utpal Bhattacharya, Hazem Daouk, 'The World Price of Insider Trading' (2002) LVII Journal of Finance.

\section{Laman}

Indonesia SIPF Securities Investor Protection Fund, 'Bulletin April 2018, Wajah Baru Indonesia SIPF', <http://www.indonesiasipf.co.id/uploads/media/ isipfbulletin2018q1.pdf $>$.

Indonesia SIPF Securities Investor Protection Fund, 'Dana Perlindungan Pemodal', $<$ http://www.indonesiasipf.co.id/dana-perlindungan-pemodal $>$.

Indonesia SIPF Securities Investor Protection Fund, 'Definisi', $<$ http://indonesiasipf. co.id/ dana-perlindungan-pemodal $>$.

Indonesia SIPF Securities Investor Protection Fund, 'Perlindungan Pemodal', 
$<$ http:// indonesiasipf.co.id/perlindungan-pemodal $>$.

Indonesia SIPF Securities Investor Protection Fund, 'Tahapan Penanganan Klaim', $<$ http://indonesiasipf.co.id/perlindungan-pemodal $>$.

No name, 'Pengertian dan Contoh Emiten', <http://istilah-istilahsaham.blogspot. com/2017/09/sumber-sahamok.html>.

No name, 'Perbedaan Emiten dan Perusahaan Publik', <https://www.sahamok. com/perbedaan-emiten-dan-perusahaan-publik/>.

Sovia Hasanah, 'Perbedaan Perseroan Terbuka dengan Perseroan Publik', $<$ https://www.hukumonline.com/index.php/klinik/detail/lt59d19e8d6de3d/ perbedaan-perseroan-terbuka-dengan-perseroan-publik $>$.

Tahir Saleh, 'Perhatian! Emiten Pailit, SIPF Tak Ganti Dana Investor', <https:// www. cnbcindonesia.com/market/20190508105900-17-71193/perhatianemiten-pailit-sipf-tak-ganti-dana-investor> .

\section{Tesis}

Christma Dasse Ardhani, 'Perlindungan Hukum Terhadap Pemegang Saham Minoritas Perusahaan Publik' (2016) Tesis Fakultas Hukum Universitas Airlangga.

Haniefa Effendi, 'Perlindungan Bagi Pemegang Obligasi Dengan Jaminan Property (Mortgage Bond) dan Obligasi Dengan Jaminan Guarantor (Guarantor Bond)' (2017) Tesis Fakultas Hukum Universitas Airlangga.

\section{Perundang-Undangan}

Undang-Undang Nomor 8 Tahun 1995 tentang Pasar Modal (Lembaran Negara Republik Indonesia Tahun 1995 Nomor 64, Tambahan Lembaran Negara Republik Indonesia Nomor 3608).

Undang-Undang Nomor 40 Tahun 2007 tentang Perseroan Terbatas (Lembaran Negara Republik Indonesia Tahun 2007 Nomor 106, Tambahan Lembaran Negara Republik Indonesia Nomor 4756).

Undang-Undang Nomor 21 Tahun 2011 tentang Otoritas Jasa Keuangan (Lembaran Negara Republik Indonesia Tahun 2011 Nomor 111, Tambahan Lembaran Negara Republik Indonesia Nomor 5253).

Peraturan Pemerintah Nomor 45 Tahun 1995 tentang Penyelenggaraan Kegiatan di 
Bidang Pasar Modal.

Peraturan Otoritas Jasa Keuangan Nomor 49/POJK.04/2016 tentang Dana Perlindungan Pemodal.

Peraturan Otoritas Jasa Keuangan Nomor 50/POJK.04/2016 tentang Penyelenggara Dana Perlindungan Pemodal.

Keputusan Ketua Bapepam Nomor Kep-86/PM/1996 perihal Peraturan Nomor X.K.1 tentang Keterbukaan Informasi Yang Harus Segera Diumumkan Kepada Publik.

Keputusan Anggota Dewan Komisioner Otoritas Jasa Keuangan Nomor KEP46/D.04/2015 tentang Perubahan Atas Keputusan Anggota Dewan Komisioner Otoritas Jasa Keuangan Nomor KEP-70/D.04/2013 tentang Penetapan Batasan Paling Tinggi Untuk Setiap Pemodal Dan Setiap Kustodian Dalam Rangka Pembayaran Ganti Rugi Kepada Pemodal Dengan Menggunakan Dana Perlindungan Pemodal.

Keputusan Anggota Dewan Komisioner Otoritas Jasa Keuangan Nomor KEP62/D.04/2016 tentang Penetapan Besaran Imbalan Jasa Pengelolaan Atas Investasi Dana Perlindungan Pemodal Oleh PT. Penyelenggara Program Perlindungan Investor Efek Indonesia.

Surat Edaran Otoritas Jasa Keuangan Nomor 18/SEOJK.04/2013 tentang Kriteria Pernyataan Tertulis Oleh Otoritas Jasa Keuangan dan Tata Cara Penentuan Nilai Aset Pemodal Yang Hilang, Dalam Rangka Penggunaan Dana Perlindungan Pemodal.

HOW TO CITE: Mohammad Solehodin Attijani, 'Penyelenggara Dana Perlindungan Pemodal Bagi Investor Dalam Transaksi Saham Pada Pasar Modal' (2019) Vol. 2 No. 2 Media Iuris. 
--Halaman ini sengaja dikosongkan-- 